RU Валентность и семантика предиката как фактор детерминации референциального потенциала наименования лица (на материале английского и татарского языков)

\author{
Ибрагимова Э. Р.
}

\begin{abstract}
Аннотация. Цель исследования - выявить основные синтаксические особенности английского и татарского каузативных высказываний, детерминированные валентностью и семантикой предиката, с последующим проведением их сопоставительного анализа. В статье рассматриваются особенности актантной организации высказываний с семантикой каузации, содержащих наименования лица в роли субъекта. Особое внимание уделяется сходствам и различиям английских и татарских синтаксических конструкций заявленной семантики. Научная новизна работы определяется незначительной степенью изученности высказываний с наименованием лица в своем составе, обладающих каузативной семантикой. В результате установлено, что валентность и семантика глагола определяют возможность альтернации наименований лица и события в роли субъекта и, следовательно, детерминируют реализацию референциального или интерпретационного статусов наименований лица.
\end{abstract}

\title{
as Factor in Determining Referential Potential of Name of Person (by the Material of the English and Tatar Languages)
}

\author{
Ibragimova E. R.
}

\begin{abstract}
The purpose of the study is to identify the main syntactic features of the English and Tatar causative utterances determined by valency and semantics of the predicate, with their subsequent contrastive analysis. The article deals with features of actant organisation of utterances with semantics of causation containing names of a person in the role of the subject. Special attention is paid to similarities and differences between the English and Tatar syntactic constructions of the said semantics. Scientific novelty of the work is determined by the fact that utterances with causative semantics containing a name of a person have not been studied to a sufficient degree. As a result, it was found that valency and semantics of the verb provide a possibility of alternation of names of a person and event in the role of the subject and, therefore, determine realisation of referential or interpretational statuses of names of a person.
\end{abstract}

\section{Введение}

Каузация является одним из наиболее проблематичных вопросов в описании языка, которому посвящены труды отечественных и зарубежных ученых, но по сей день этот вопрос остается недостаточно освещенным в лингвистических трудах по татарскому языку, а также с позиций сравнительного и сопоставительного языкознания. Актуальность темы связана с необходимостью изучения выражений с наименованием лица и семантикой каузации как в английском, так и в татарском языках. Анализ семантики рассматриваемых синтаксических конструкций способствует устранению трудностей при выборе каузативного глагола, сочетающегося с именем лица, у изучающих английский или татарский язык.

Для достижения поставленной цели необходимо решить следующие задачи:

- установить причину реализации референциального или интерпретационного статусов наименований лица в выражениях каузации;

- установить, могут ли наименования лица в обоих изучаемых языках выступать обозначением события в свернутой форме;

- выявить условия возникновения альтернации наименований лица и событий в роли субъекта в выражениях каузации; 
- определить сходства и различия каузативных выражений английского и татарского языков с точки зрения их синтаксической структуры.

В работе использованы методы сплошной выборки, функционально-семантического, компонентного и сопоставительного анализа. Эмпирической базой исследования стали примеры из лингвистических корпусов двух языков - British National Corpus (далее BNC) и Письменного корпуса татарского языка (далее ПКТЯ). В процессе исследования было проанализировано более 25 высказываний.

Теоретической базой исследования послужили труды А. А. Холодович (1969), Г. А. Золотовой (1973), К. Г. Крушельницкой, определяющих каузативность как грамматическую категорию неморфологического типа [9, с. 7]; Н. Д. Арутюновой (1976), которая рассматривает синтаксические механизмы каузации как возможность взаимодействия имен лица и обозначений событий в структуре предложения. Важным аспектом исследования стали идеи А. Мустайоки, рассматривающего категорию каузации на синтаксическом уровне в качестве модификатора высказывания, функция которого заключается в расширении семантической структуры и влиянии на синтаксическую структуру высказывания [6, с. 277]. В данной работе вслед за Мустайоки мы обратимся к анализу синтаксической структуры каузативных высказываний с наименованием лица. Предметом анализа являются высказывания каузации английского и татарского языков с наименованиями лица.

Практическая значимость работы заключается в возможности использовать ее выводы при разработке теоретических курсов по грамматике и лексикологии татарского и английского языков, при составлении двуязычных словарей, при написании учебных пособий по языковой практике и переводу, а также на практических занятиях при обучении языку. Материалы и результаты исследования могут быть использованы в ряде смежных дисциплин - лингвокультурологии, теории и практике перевода.

\section{Реализация референциального статуса наименований лица}

Референциальный статус, как известно, предполагает высказывание о вполне конкретных людях, номинация которых может быть представлена именем собственным как идентификатором или наименованием лица как именем нарицательным с определенной/неопределенной референцией.

В науке о языке приняты различные варианты семантического треугольника, но общность содержания присутствует во всех терминологических вариантах (Таблица 1).

Таблица 1. Термины выражения семантического единства в плане выражения и плане содержания

\begin{tabular}{|c|c|c|}
\hline 1 & Принятое в человеческом обществе наименование лица & Слово, имя, знак, номинация \\
\hline 2 & $\begin{array}{l}\text { Возникающий в сознании людей мысленный образ о данном } \\
\text { представителе класса лиц }\end{array}$ & $\begin{array}{l}\text { Понятие, } \\
\text { референция, } \\
\text { десигнат (Августин), } \\
\text { сигнификат (Ч. Моррис), } \\
\text { означаемое (Ф. Соссюр), } \\
\text { смысл (Г. Фреге), } \\
\text { значение (У. Куайн), } \\
\text { интенсионал (Р. Карнап) }\end{array}$ \\
\hline 3 & Данное в ощущениях лицо реальной действительности & $\begin{array}{l}\text { Лицо, } \\
\text { денотат (Б. Рассел, А. Черч, У. Куаян), } \\
\text { референт (Ч. Огден, А. Ричардс), } \\
\text { экстенционал (Р. Карнап) }\end{array}$ \\
\hline
\end{tabular}

Приведенная таблица достаточно наглядно демонстрирует, что нереференциальные статусы принадлежат ко второму уровню понятий и образов. Так, в рассуждениях общего характера, где не подразумеваются какие-то конкретные люди, наименования лица не обладают референциальным потенциалом, а стремятся выразить экзистенциальное, родовое или универсальное нереференциальные значения:

(1) A thief rarely shows self-confidence [10]. / Карак үз-үзенә ышанычны сирәк күрсәтә. / Вор редко демонстрирует уверенность в себе (здесь и далее перевод выполнен автором статьи. - Э. И.).

(2) һәр ишегалдында ишегалды қыештыручы эшли [7]. / Each yard has a janitor. / В каждом дворе работает дворник.

(3) Барлык кызлар да чәчәкләр бәйләмнәрән алырга ярата [Там же]. / All girls love getting flowers for the holidays. / Все девушки любят получать цветы на праздники.

Из приведенных примеров видно, что родовой нереференциальный статус характерен для умозаключений о категории людей с указанием на одного представителя (1). Экзистенциальный статус предполагает существование какого-либо представителя человечества (2). Универсальный статус подразумевает весь класс лиц в целом (3).

Референциальный статус определяет переход на третий уровень связи с конкретным лицом действительности.

Для более точного понимания проблемы обратимся к неоднозначной трактовке самого понятия референции. Референция может быть лингвистической и экстралингвистической. Экстралингвистическая референция как связь с конкретным объектом действительности присуща предметным и одушевленным/неодушевленным конкретным именам существительным. К лингвистической референции мы относим такие понятия, 
как предикативная референция и автономная референция. Предикативная референция, как специфическая особенность наименований лица, характеризует данные существительные в синтаксической функции предиката, например:

(4) These girls are secretaries [10]. / Бу кызлар-секретарьлар. / Эти девушки - секретарши.

Автономная референция реализуется в высказываниях типа:

(5) Rocking chair is a name of the type of armchairs [Ibidem]. / Атынгыч кәнәфи - бу кәнәфи төре. / Креслокачалка - это название вида кресел.

На первый взгляд референциальный статус наименований лица эквивалентен статусу предметных имен существительных, то есть предметное и живое в языке одинаково реализуют референциальную конкретизацию. Однако основное отличие имен лица связано с существованием имен собственных, которые, согласно приведенной выше Таблице 1, лишены второго уровня понятия и являются «чистыми» идентификаторами. Идентификация происходит напрямую посредством привязывания наименования к конкретному субъекту в момент имянаречения (включая все одушевленные существа, например: кошка Мурка, и даже неодушевленные, например: кафе «Аленка»). Еще одно коренное отличие заключается в том, что при общих принципах конкретизации наименования лица обладают специфической особенностью - репрезентируя участников той или иной ситуации, они могут подразумевать в высказывании ситуацию в целом, хотя, как справедливо заметила Н. Д. Арутюнова, «наименования лица в функции репрезентации ситуации менее семантически информативны. Они несут в себе смысл, который окказионально закреплен за ними в данном высказывании» [3, с. 116].

\section{Наименования лица как обозначение события}

Наименование лица может отсылать нас не только к конкретному участнику события, а к событию в целом:

(6) Кыз дусты аркасына таеп егыла язды [7]. / Girl slipped because of her friend. / Девочка поскользнулась из-за своей подруги (= из-за того, что она ее толкнула, задела). Подруга = ситуация с ее участием.

Приведенный пример демонстрирует способность имени подразумевать ситуацию в целом. Данная особенность наименований лица проявляется только в рамках высказывания и связана, на наш взгляд, исключительно с понятием лингвистической референции.

Принято считать, что способностью соотноситься своей референцией с ситуацией в целом обладают глаголы, это их основное качество. Выходит, что наименования лица отсылают нас к ситуации в целом и ведут себя, как глаголы? Это невозможно с точки зрения онтологической референции, но вполне допустимо с позиций лингвистической референции. В данном случае наименование лица не обладает классическим референциальным значением указания на лицо действительности, его статус носит интерпретационный характер. Наименование лица подразумевает ситуацию в целом, реализуя такой вид лингвистической референции, который мы предлагаем называть интерпретационным референциальным статусом.

\section{Условия возникновения альтернации наименований лица и событий}

Для наименований лица типичным является функционирование в высказываниях каузативной семантики, где «ядром функционально-семантического поля каузативности является каузативный глагол» [8, с. 156]. Как утверждает А. В. Бондарко, «любая функционально-семантическая категория имеет структуру поля, основополагающим свойством которого является общность семантической функции средств разных языковых уровней» [4, с. 77]. Так, ведущей семой, присущей каузативным глаголам как функционально-семантическому разряду глаголов, является сема воздействия. А описанная выше возможность альтернации наименований лица и событий и, следовательно, реализация референциального или интерпретационного статусов наименований лица в выражении каузации во многом определяются не только семантикой, но и валентностью глагола.

Валентность глагола, в свою очередь, определяет объем его семантики. Можно выделить следующие типы глаголов исходя из их валентности.

- По определению А. Д. Арутюновой, скрытые двухагентивные и одноагентивные глаголы содержат в своем значении указание на две ситуации [2, с. 344]: ‘кормить’ может означать и 'давать пищу’ (каузирующее событие), и 'принимать пищу’ (о другом агенте). Двухагентивные каузативы соединяют между собою имена двух лиц - протагонистов двух событий. Одна валентность заполняется подлежащим или субъектом, другая валентность - прямым дополнением или объектом. Необходимо отметить, что альтернация в субъектной позиции имен лиц и имен событий допускается не всеми глаголами. Например, предложение (7) не может быть преобразовано в предложение (8).

(7) Dad fed the baby [10]. / Әтисе сабыйны ашатты. / Отец накормил малыша.

(8) Әтисе сабыйны сүзләр (янаулар, үтенечләр) белән ашаткан [7]. / Dad fed the baby with words (threats, requests). / Папа накормил малыша словами (угрозами, просьбами).

Два реальных акта, осуществляемых двумя разными лицами, представлены в приведенном предложении как одно событие (7), центром которого является предикат двойного механического действия.

В представленных примерах на английском и татарском языках актант- инструмент не является обязательным. Наименования лиц как обозначения участников одной ситуации часто объединяются двухагентивными каузативными глаголами, «показатель ситуативных отношений в которых глубоко спрятан в их лексическое значение, он не выходит на уровень синтаксического оформления» [5, с. 88]. Данные глаголы указывают 
на два события и связывают их отношениями каузации. Они выражают «чистые» действия, в их семантику не входит импликация участников. Межситуационный логический компонент не может оказать влияние на актантную рамку этих глаголов и ее возможные модификации. Ситуационные глаголы нуждаются в отдельной номинации участников, им требуется экспликация путем использования наименований лиц. В высказываниях с данными глаголами реализуется референциальный статус наименований лица при условии исключения рассуждений общего характера, хотя они и не свойственны для подобных предикатов.

- $\quad$ Трехвалентные глаголы предполагают заполнение трех актантных валентностей. К таковым можно отнести, например, глаголы аффективного воздействия:

(9) The kidnappers persuaded the victim to open the door [10]. / Караклар корбанны ишек ачарга күндерделәр. / Похитители уговорили жертву открыть дверь.

Позиция актанта-инструмента не нуждается в заполнении. Первая валентность всегда заполняется субъектом, вторая - объектом, третья валентность и в английском, и в татарском примерах заполнена инфинитивной конструкцией to open the door / ишек ачарга (9). Содержание данных глаголов не охватывает ни номинации ситуации, ни ее участника. Им необходима экспликация участника и самой ситуации. Наименования лица в подобных высказываниях реализуют референциальное значение в соответствии с общими правилами, одновременно допуская и реализацию альтернативного интерпретационного статуса.

- Трехвалентные глаголы реализуют значение каузации путем воздействия, сознательного или непроизвольного, на волю лица:

(10) The teacher's word (The teacher by her words) kept the girl from a stupid act [Ibidem]. / Укытучынын сүзе (укытучы сүзе белән) кызны ахмаклык гамәленнән тотып кала. / Учитель словом удержал девочку от глупого поступка.

Первая валентность всегда заполняется субъектом, вторая - прямым объектом, третья валентность заполнена косвенным объектом, введенным в английском языке предлогом from, а в татарском языке - формой исходного падежа ахмаклык гамәленнән. Актант-инструмент представлен в русском переводе существительным в дательном падеже - 'словом’. В английском и татарском языках данный актант объединен в группу подлежащего, то есть инструмент выступает в роли субъекта с указанием его принадлежности, выраженной наименованием лица. В результате не лицо принимает роль субъекта, а инструмент - лица.

За пределами семантики данных глаголов остаются обозначения обоих лиц и обоих событий (10). Как можно увидеть из примера (10), и в английском, и в татарском примерах реализованы все три валентности глагола.

Как видим, некоторые глаголы допускают альтернацию наименований лица и событий в позиции субъекта, как в примерах (9), (10): похититель уговорил = уговоры похитителя; учитель удержал = слова учителя удержали, так и в следующих выражениях:

(11) Her refusal forced him to leave [Ibidem]. / Аның баш тартуы аны китәргә мәжбүр итте. / Ее отказ вынудил его уехать.

(12) She forced him to leave with her refusal [Ibidem]. / Үзенен баш тартуы белән ул аны китәргә мәжбүр итте. / Она вынудила его уехать своим отказом.

В английском примере (12) агенс каузатор представлен местоимением третьего лица, замещающим другое наименование лица с определенным референциальным статусом. Глагол 'force' в корпусе английского языка наиболее частотен в страдательном залоге: 'He was forced to do something', то есть в английском языке каузатор зачастую остается за рамками высказывания, важность приобретает лишь указание на изменившееся положение дел.

При альтернации может происходить расщепление субъекта на наименование участника и обозначение ситуации. При расщепленном обозначении каузирующего события предикат обычно сохраняет при себе показатель агента:

(13) Әби оныкларын онытучанлыгы белән газаплый [7]. / Grandmother torments her grandchildren with her forgetfulness. / Бабушка мучает внуков своей забывчивостью.

Раздвоение каузирующего события имеет своим следствием чередование в позиции подлежащего имени лица и событийной лексики. Субъект-лицо предполагает расщепленную, субъект-пропозиция - целостную номинацию события [1, с. 153-156]. При этом «субъект действия как бы выделяется из события и приобретает в строе предложения обособленную (причем двойную - объекта воздействия и субъекта действия) функцию» [3, с. 342].

Синтаксическая позиция для экспликации «причинности»в английских выражениях каузации очень часто может быть представлена сочетанием Obj + инфинитива глагола, выражающим каузируемое действие, так называемым сложным дополнением, которому в татарском языке, как правило, соответствует простая инфинитивная конструкция:

(14) I made him drink some water [10]. / Мин аны бераз су эчәргә мәжбүр иттем [7]. / Я заставил его выпить немного воды.

\section{Заключение}

Таким образом, на основании анализа эмпирического материала сделаны следующие выводы о лингвистических особенностях синтаксической структуры английского и татарского высказывания каузативной семантики, включающего наименования лица:

- реализация референциального или интерпретационного статусов наименований лица в выражениях каузации детерминирована валентностью и семантикой глагола; 
- наименования лица обоих языков могут выступать обозначением события в свернутой форме, но альтернация в субъектной позиции имен лиц и имен событий допускается не всеми глаголами;

- возможность альтернации наименований лица и событий в роли субъекта определяются валентностью и семантикой глагола;

- в английском и татарском языках выявлены идентичные инфинитивные конструкции и явления стяжения актанта-инструмента и агенса отношениями принадлежности в одну группу субъекта.

Изучение данного вопроса не останавливается, и перспективой дальнейшего исследования может стать функционально-семантический анализ высказываний каузации в английском и татарском языках с учетом их прагматики.

\section{Список источников}

1. Апресян Ю. Д. О расщеплении валентностей // Апресян Ю. Д. Избранные труды: в 2-х т. М.: Школа «Языки русской культуры», 1995. Т. 1. Лексическая семантика. Синонимические средства языка. С. 119-156.

2. Арутюнова Н. Д. Положение имен лица в русском синтаксисе // Известия АН СССР. Литература и язык. 1975. Т. 34. № 4. С. 341-350.

3. Арутюнова Н. Д. Предложение и его смысл: логико-семантические проблемы. Изд-е 4-е, стер. М.: Едиториал URSS, 2005. 384 с.

4. Бондарко А. В. Теория грамматических категорий. Л.: Слово, 1976. 255 с.

5. Лутфуллина Г. Ф. Квантификация актантов при предикатах, каузирующих обладание (на материале французского и татарского языков) // Инновационная наука. 2015. Т. 3. № 5. С. 87-89.

6. Мустайоки А. Теория функционального синтаксиса: от семантических структур к языковым средствам. М.: Языки славянской культуры, 2006. 512 с.

7. Письменный корпус татарского языка [Электронный ресурс]. URL: https://www.corpus.tatar/ (дата обращения: 17.12.2020).

8. Фомичева Е. В. Средства выражения побудительности в английском языке в свете семантики и прагматики // Современные проблемы науки и образования. 2009. № 4. С. 156-162.

9. Шустер А. Г. Категория следствия и средства ее реализации на разных ярусах синтаксиса в современном русском языке: автореф. дисс. ... к. филол. н. Армавир, 2005. 29 с.

10. British National Corpus [Электронный ресурс]. URL: https://www.english-corpora.org/bnc/ (дата обращения: 17.12.2020).

\section{Информация об авторах | Author information}

RU Ибрагимова Эльмира Рафаилевна ${ }^{1}$, к. филол. н., доц.

${ }^{1}$ Казанский государственный энергетический университет

EN Ibragimova Elmira Rafailevna ${ }^{1}, \mathrm{PhD}$

${ }^{1}$ Kazan State Power Engineering University

${ }^{1}$ zamelma@list.ru

\section{Информация о статье | About this article}

Дата поступления рукописи (received): 10.01.2021; опубликовано (published): 26.02.2021.

Ключевые слова (keywords): высказывание каузации; актантная рамка; наименование лица; референциальный потенциал; семантика предиката; utterance of causation; actant frame; name of person; referential potential; semantics of predicate. 